\title{
BIOACOUSTIC ANALYSIS OF ADVERTISEMENT CALL IN Hyla nana AND Hyla sanborni (ANURA, HYLIDAE) IN BOTUCATU, SÃO PAULO, BRAZIL
}

\author{
MARTINS, I. A. ${ }^{1}$ and JIM, J. ${ }^{2}$ \\ ${ }^{1}$ Universidade de Taubaté, UNITAU, Depto. de Biologia, Lab. de Zoologia, CEP 12030-010, Taubaté, SP, Brazil \\ ${ }^{2}$ Universidade Estadual Paulista, UNESP, Depto. de Zoologia, Campus de Botucatu, CEP 18618-000, \\ Botucatu, SP, Brazil \\ Correspondence to: Itamar A. Martins, Universidade de Taubaté, UNITAU, Depto. de Biologia, Lab. de Zoologia, \\ Praça Marcelino Monteiro, 63, CEP 12030-010, Taubaté, SP, Brazil, e-mail: istama@uol.com.br \\ Received November 20, 2002 - Accepted January 15, 2003 - Distributed August 31, 2003
}

(With 4 figures)

\begin{abstract}
Vocal communication traits of Hyla nana and Hyla sanborni, of the nana species group, were studied from August 1997 until June 1999 in two large permanent ponds located in an open field in Botucatu, São Paulo State. One hundred thirty-one individuals, 71 of $H$. nana and 58 of $H$. sanborni, were recorded in the beginning of their vocalization activity and during chorus vocalization. The rhythms of sound emission on the two occasions were different. An advertisement call consists in a consecutive series of simple notes in rapid succession. Both species have two types of notes in their advertisement calls, here named types A and B. Type A notes are introductory and have a longer and higher pulse number and are emitted more frequently in the beginning of vocalization activity. Introductory notes are the first to be emitted in chorus activity. Type B notes are secondary, of shorter duration and lower pulse number, and are emitted during chorus vocalization. The notes of both types differ significantly in their temporal structure. Both species present acoustic segregation in both spectral and temporal structure.
\end{abstract}

Key words: anurans, Hyla nana, Hyla sanborni, bioacoustics, advertisement call.

\section{RESUMO}

\section{Análise bioacústica do canto de anúncio em Hyla nana e Hyla sanborni na região de Botucatu, Estado de São Paulo, Brasil}

As características relacionadas à comunicação sonora em duas espécies aparentadas, Hyla nana e H. sanborni, pertencentes ao grupo nana de espécies, foram estudadas, entre agosto de 1997 e junho de 1999, em duas poças permanentes de grande porte em área aberta na região de Botucatu, Estado de São Paulo. Foram obtidas gravações de 131 exemplares, 71 indivíduos de H. nana e 58 de H. sanborni, durante início de atividade de vocalização e atividade de vocalização em coro. Houve diferença nos ritmos de emissão de notas dos cantos entre o início das atividades e durante os coros. O canto de anúncio das espécies consiste na emissão de séries consecutivas de notas simples, pulsadas, com taxa de repetição rápida. Hyla nana e $H$. sanborni apresentam dois tipos de notas em seu canto de anúncio, denominados aqui como tipos A e B. Notas do tipo A, introdutórias, apresentam maior duração e número de pulsos, e suas emissões foram mais freqüentes durante o início das atividades de vocalização. As notas introdutórias são as primeiras da série emitida em atividade de coro. As notas do tipo B, secundárias, são curtas e com menor número de pulsos, sendo emitidas durante as vocalizações em coro. Os dois tipos de notas encontrados diferem significativamente em sua estrutura temporal. As duas espécies apresentaram segregação acústica tanto na estrutura espectral como na temporal de seus cantos de anúncio.

Palavras-chave: anura, Hyla nana, Hyla sanborni, bioacustica, canto de anúncio. 


\section{INTRODUCTION}

Among the many aspects of frog behavior, vocal communication is outstanding for its importance in reproductive biology and social behavior, having originated early in the evolutionary history of the group (Salthe \& Mecham, 1974).

The essential role of vocalization in assembling individuals, maintaining spacing among them, and attracting females is well documented in the literature (e.g., Gerhardt, 1994; Ryan, 2001). Experimental demonstration of these functions, however, is not always possible. The difficulties arise in part from the heterogeneity of responses obtained in vocalization experiments (Cardoso, 1986).

In synchronopatric frog populations, advertisement calls (sensu Wells, 1977) contain spectral and/ or temporal information relevant to specific recognition (Salthe \& Mecham, 1974; Wells, 1977, 1988; Ryan, 1985; Cocroft \& Ryan, 1995). Besides transmitting information and having several roles in social organization, e.g., recruiting individuals to chorus, attracting sexual mates, acting as efficient reproductive isolating mechanisms, having a function in territorial behavior, and promoting male spacing, these calls represent adaptations that avoid or reduce acoustic interference inside or among species and have played an important role in natural and evolutionary history (Wells, 1980, 1988; Schwartz \& Wells, 1983, 1984a; Bastos \& Haddad, 1995; Grafe, 1996; Given, 1999).

The males of many species use vocal signaling in dense aggregations near environments favorable to the survival of their own offspring (Wells, 1977). Besides occupying distinct microhabitats, synchronopatric species emit vocalizations with different characteristics, permitting specific recognition and the coexistence of many species in the same environment, as demonstrated by several authors (Duellman \& Pyles, 1983; Cardoso \& Vielliard, 1990; Márquez et al., 1993; Bastos \& Haddad, 1995; Vielliard \& Cardoso, 1996).

In anurans, advertisement calls are excellent behavioral traits for comparative studies (Ryan, 1985). The calls of some sympatric species may be very similar except for certain characteristics such as temporal parameters (Passmore, 1981).

Tropical anurans communities are largely diverse, and ecological and phylogenetic relationships inside and between taxonomic groups remain unclear (De
La Riva et al., 1996a, b). Comparative studies of advertisement calls based on quantitative and qualitative parameters may provide part of the information required to solve these puzzles (Márquez et al., 1993).

Hyla nana and Hyla sanborni, the two species studied here, belong to the nana species group (Frost, 1985) and were selected because they are closely related, have the same body size and similar vocalizations, and live in the same environments. Our purpose was to study the advertisement calls of both species, investigating their spectral and temporal structures in the beginning of vocalization activity and during chorus vocalization.

\section{MATERIALS AND METHODS}

Field observations and recordings were made in two open-area environments in Botucatu, São Paulo State.

Environment I. This was a $120 \times 50 \mathrm{~m}$ pond, located $\left(22^{\circ} 53^{\prime} 08^{\prime \prime} \mathrm{S}\right.$ and $\left.48^{\circ} 29^{\prime} 24^{\prime \prime} \mathrm{W}\right)$ at an altitude of $860 \mathrm{~m}$. Jim (1980) described it as large and permanent, with continuous water renewal. The margins are swampy, with mainly herbaceous vegetation represented by Poaceae and Cyperaceae.

Environment II. This was a $100 \times 70 \mathrm{~m}$ pond, located (22 $57^{\prime} 03^{\prime \prime} \mathrm{S}$ and $\left.48^{\circ} 27^{\prime} 36^{\prime \prime} \mathrm{W}\right)$ at an altitude of $810 \mathrm{~m}$. Jim (1980) considered this environment a headwaters swamp inside savanna (cerrado). It is also large, permanent, and has continuous water renewal and mainly herbaceous vegetation represented by Poaceae and Cyperaceae.

Field activities were carried out from August 1997 through June 1999. Visits occurred every other week from nightfall (17:00) to the period of decreased vocalization activity (24:00 to $02: 30$ ).

Behavioral information was obtained using Martin \& Bateson's (1986) "focal animal" method, with sampling periods varying from one to 10 minutes, but reaching up to 30 minutes, mainly for observation of intra- and interspecific interactions.

The time when vocalization activity began and when it reached its peak (chorus) were recorded. At intervals of approximately one hour, the number of vocalizing males was estimated.

To study intra- and interspecific interactions, individuals in the beginning of their vocalization activity and during chorus vocalization were compared and possible differences in both behavior and spectral and temporal structure were sought. 
The vocalizations were recorded under field conditions with a Sony TCD-D8 digital recorder (DAT) and a Sony TCM-S64V analog cassette recorder coupled to external directional (ME 67), semidirectional (ME 66), or cardioid (ME 64) Sennheiser microphones. All vocalizations recorded were edited and filed on 2.0 GB optic disks and also on high-density diskettes, with a sampling rate of $44.100 \mathrm{~Hz}$ and 16 bits per sample in the mono pattern, in format "Windows PCM" and "Next/Sun [*au, *.snd]" archives.

The bioacoustic analyses were performed in a microcomputer using the program CoolEdit 96 (Syntryllium Software Corporation), with a 20.000 $\mathrm{Hz}$ sampling frequency. The 256 points option (Fast Fourier Transform, FFT) and, when necessary, the 1024 points option was used, mainly in determining fundamental frequencies.

Nine traits of the advertisement call of both species were analysed: frequency band, fundamental frequency (dominant frequency), pulse number per note, pulse duration, pulse repetition rate, note duration, note repetition rate, number of notes per sequence, and sequence duration.

At the beginning and end of each field research period and at the beginning of every vocalization recording, air and water temperature were measured with a $0.5^{\circ} \mathrm{C}$ precision mercury thermometer. The specimens whose calls were recorded are now in the personal collection of Dr. Jorge Jim (Departamento de Zoologia, Instituto de Biociências, Universidade Estadual Paulista, Botucatu, São Paulo) and had their snout-vent length (SVL) measured with a $0.01 \mathrm{~mm}$ precision caliper.

The intra- and interspecific comparison of call traits were studied through variance analysis (ANOVA) and afterwards complemented by the Student-Newman-Keuls test (Ayres et al., 2000); the Mann-Whitney rank sum test was used to compare two variables when they did not present normal distribution.

For analyses and bioacustic interpretations the following terms were used:

Vocalization/call: a set of sounds produced in a certain sequence constituted by either a single note (simple call) or a series of identical notes or groups of different notes (composite call) emitted in definite temporal patterns.

Note: temporally uninterrupted sound element composing the call and made up of pulses.
Introductory note: the first note of a series, differing from the remaining notes of the series or sequence by having a different temporal and/or spectral structure.

Secondary notes: the notes subsequent to the introductory note of a series or sequence.

Pulses: sounds of extremely short duration produced by a single energy release. They are the energy impulses emphasized in the temporal spectrum of a note.

Series or sequence: a succession of notes forming a regularly repeated unit.

Repetition rate: the frequency at which a note, a note sequence, or note pulses are repeated. It is measured from the beginning of one sequence, note, or pulse to the beginning of the next.

Interval between notes and sequences: the time elapsed from the end of a note or sequence to the beginning of the next note or sequence.

Frequency: one of the defining characteristics of sound, it is the inverse of the period and is measured in $\mathrm{Hz}$ or $\mathrm{kHz}$ (hertz or kilohertz). The frequency band is the interval of frequencies occupied by sound.

Dominant frequency: frequency at which a call and/or note presents the highest intensity (energy); measured in $\mathrm{Hz}$ or $\mathrm{kHz}$ (dominant frequency, Duellman, 1970, a term also used by other authors).

Fundamental frenquency: the lower harmonic in the frequency spectrum.

Harmonic $(\mathbf{H})$ : an integral multiple of the fundamental frequency.

Spectral structure: frequency bands occupied by sounds (with or without harmonics).

Temporal structure: fixed or unfixed organization, duration, rhythm, and pulse rate of notes and sequences.

These definitions were adapted from Duellman (1970), Duellman \& Pyles (1983), Duellman \& Trueb (1986), and Ryan (2001).

\section{RESULTS}

Recordings of 131 individuals, 71 of $H$. nana and 58 of $H$. sanborni, were obtained. The snoutvent length (SVL) of the males studied are as follows: H. nana, $22.48 \pm 1.26 \mathrm{~mm}$ (19.7 to $24.3 \mathrm{~mm}$ ); and H. sanborni, $18.11 \pm 1.87 \mathrm{~mm}$ ( 15.7 to $22.89 \mathrm{~mm}$ ).

The characteristics of the advertisement call of the two species are summarized in Table 1. 
TABLE 1

Characteristics of nine variables of the advertisement call of Hyla nana and Hyla sanborni in the beginning of vocalization activity (notes type $A$ ) and during chorus vocalization (notes type B). Figures include average \pm standard deviation, amplitude, and sample size.

\begin{tabular}{|c|c|c|c|}
\hline \multicolumn{2}{|c|}{ Characteristics } & H. nana & H. sanborni \\
\hline \multicolumn{2}{|l|}{$\begin{array}{l}\text { Frequency bands }(\mathrm{Hz}) \\
\text { (notes type } \mathbf{A} / \mathbf{B})\end{array}$} & $\begin{array}{c}2,950-4,850 \\
\pm 350 ; \mathrm{n}=780 \\
(2,600-5,500)\end{array}$ & $\begin{array}{c}3,860-5,950 \\
\pm 300 ; \mathrm{n}=921 \\
(3,600-6,450)\end{array}$ \\
\hline \multicolumn{2}{|c|}{$\begin{array}{l}\text { Fundamental frequency }(\mathrm{Hz}) \\
\text { (notes type } \mathbf{A} / \mathbf{B} \text { ) }\end{array}$} & $\begin{array}{c}3,000-4,500 \\
\pm 200\end{array}$ & $\begin{array}{c}4,000-5,500 \\
\pm 300\end{array}$ \\
\hline \multirow[t]{2}{*}{ Number pulse per note } & $\begin{array}{l}\text { Initial call } \\
\text { (type A) }\end{array}$ & $\begin{array}{c}11 \pm 3 \\
(7-15) n=103\end{array}$ & $\begin{array}{c}5 \pm 2 \\
(3-8) \mathrm{n}=134\end{array}$ \\
\hline & $\begin{array}{l}\text { Chorus } \\
\text { (type B) }\end{array}$ & $\begin{array}{c}4 \pm 1 \\
(3-5) n=192\end{array}$ & $\begin{array}{c}4 \pm 1 \\
(3-6) n=201\end{array}$ \\
\hline \multirow[t]{2}{*}{ Pulse duration (ms) } & Initial call & $\begin{array}{l}2.54 \pm 0.61 \\
(2-3) \mathrm{n}=103\end{array}$ & $\begin{array}{c}4.55 \pm 0.86 \\
(3-6) n=134\end{array}$ \\
\hline & Chorus & $\begin{array}{c}2.7 \pm 0.61 \\
(2-4) n=192\end{array}$ & $\begin{array}{c}4.02 \pm 0.94 \\
(3-6) n=201\end{array}$ \\
\hline \multirow[t]{2}{*}{ Pulse repetition rate $(\mathrm{ms})$} & Initial call & $\begin{array}{c}3.98 \pm 0.85 \\
(3-5) \mathrm{n}=106\end{array}$ & $\begin{array}{l}6.84 \pm 0.69 \\
(6-8) n=97\end{array}$ \\
\hline & Chorus & $\begin{array}{l}4.06 \pm 0.66 \\
(3-5) \mathrm{n}=218\end{array}$ & $\begin{array}{c}7.54 \pm 0.49 \\
(6-9) n=154\end{array}$ \\
\hline \multirow[t]{2}{*}{ Note duration (ms) } & Initial call $(\mathbf{A})$ & $\begin{array}{c}44.4 \pm 9.16 \\
(29-61) \mathrm{n}=203\end{array}$ & $\begin{array}{c}38.2 \pm 9.7 \\
(26-65) \mathrm{n}=249\end{array}$ \\
\hline & Chorus $(\mathbf{B})$ & $\begin{array}{c}20 \pm 3 \\
(17-26) n=216\end{array}$ & $\begin{array}{c}30 \pm 5.4 \\
(20-39) \mathrm{n}=126\end{array}$ \\
\hline \multirow[t]{2}{*}{$\begin{array}{l}\text { Note repetition rate } \\
\text { (note/sec.) }\end{array}$} & Initial call $(\mathbf{A})$ & $\begin{array}{c}1.14 \pm 0.31 \\
(0.77-2.01) \mathrm{n}=243\end{array}$ & $\begin{array}{c}1.41 \pm 0.44 \\
(0.44-2.08) \mathrm{n}=197\end{array}$ \\
\hline & Chorus (B) & $\begin{array}{c}4.73 \pm 0.87 \\
(2.75-6.51) \mathrm{n}=254\end{array}$ & $\begin{array}{c}3.67 \pm 0.70 \\
(2.25-4.76) \mathrm{n}=240\end{array}$ \\
\hline \multirow[t]{2}{*}{$\begin{array}{l}\text { Number of notes per } \\
\text { sequence }\end{array}$} & Initial call $(\mathbf{A})$ & $\begin{array}{c}8.5 \pm 4.9 \\
(2-16) \mathrm{n}=56\end{array}$ & $\begin{array}{l}10.25 \pm 4.53 \\
(3-17) \mathrm{n}=42\end{array}$ \\
\hline & Chorus $(\mathbf{A} / \mathbf{B})$ & $\begin{array}{c}16.5 \pm 7 \\
(6-32) \mathrm{n}=76\end{array}$ & $\begin{array}{c}14 \pm 6 \\
(5-27) n=72\end{array}$ \\
\hline \multirow[t]{2}{*}{ Sequence duration (sec.) } & Initial call & $\begin{array}{c}8.43 \pm 5.81 \\
(2.03-18.75) \\
\mathrm{n}=56\end{array}$ & $\begin{array}{c}7.63 \pm 3.43 \\
(1.82-16.62) \\
\mathrm{n}=42\end{array}$ \\
\hline & Chorus & $\begin{array}{c}3.81 \pm 2.17 \\
(0.94-8.76) \\
n=76\end{array}$ & $\begin{array}{c}4.46 \pm 1.62 \\
(1.48-7.12) \\
n=72\end{array}$ \\
\hline
\end{tabular}


Hyla nana Boulenger, 1889.

The advertisement call is composed by simple pulsed notes emitted in series. Two clearly distinct note types were discovered in this species and designated types A (introductory) and $\mathbf{B}$ (secondary).

Type A notes are long, with average duration of $44 \mathrm{~ms}$ ( 29 to $61 \mathrm{~ms}$ ). They have from 7 to 15 irregular pulses (Fig. 1 - A and B) with average duration of $2.5 \mathrm{~ms}$ and repetition rate of $256 \mathrm{~Hz}$ (or pulses per second). These notes are emitted at slow repetition rate, with an average of one note per second and are formed by a series of 2 to 16 notes with an average duration of 8 seconds. Each note series is followed by a silent interval of $4.1 \pm 2,5$ $\mathrm{s}(1.8-7.9 \mathrm{~s} ; \mathrm{n}=22)$.

Males emitting only type A notes were often beginning their vocalization activities or were very distant from chorus areas (hence, called isolated individuals).

Type $\mathbf{B}$ notes (Fig. 1 - C and D) are short and last 17 to $26 \mathrm{~ms}$, with an average duration of 20 ms.They are emitted more rapidly, averaging 4 notes per second, each note having 3 to 5 pulses with an average duration of $2.7 \mathrm{~ms}$ and repetition rate of 250 $\mathrm{Hz}$ (or pulses per second). The vocalizations with type $\mathbf{B}$ notes basically form the typical advertisement call during chorus activity (Fig. 1-C).

The advertisement call, therefore, is formed by long and multipulsioned introductory notes (type A) followed by sequences of 6 to 32 short notes (type B) forming repetitive series lasting 4 seconds on the average and interrupted by silent intervals $(1.8 \pm$ $0.5 \mathrm{~s} ; 0.8-2.4 \mathrm{~s}$ ).

Hyla nana presented two vocalization patterns, one with only long and multipulsioned notes, the other with introductory notes followed by short notes with a series presenting larger numbers of notes. The two call types differ clearly in temporal structure of notes, pulse number, note duration, number of notes emitted per series, and series duration (ANOVA one way, $\mathrm{p}<0.05$ ) (Table 1).

The two types of notes are not significantly different in frequency, with an average between 2950 and $4850 \mathrm{~Hz}$ (ANOVA, $\mathrm{p}<0.05$ ). The frequency band of the notes occupies a large amplitude, ranging from 2600 to $5500 \mathrm{~Hz}$. The fundamental frequency is around $3900 \mathrm{~Hz}$, with a second harmonic appearing at around $7850 \mathrm{~Hz}$ (Fig. 2).

Hyla sanborni Schmidt, 1944.

The advertisement call has similar notes clustered in consecutive series. Note duration ranges from 20 to $65 \mathrm{~ms}$, averaging $30 \mathrm{~ms}$. Pulse number is 3 to 6 per note, with an average duration of 4.5 ms and with an average repetition rate of $147 \mathrm{~Hz}$ (or pulses per second) (Table 1).

The advertisement call occupies a frequency band ranging from 3860 to $5950 \mathrm{~Hz}$ (Fig. 3), with a variation of 3600 and $6450 \mathrm{~Hz}$; its fundamental frequency is around $5100 \mathrm{~Hz}$ (Fig. 4).

Two types of emission rhythms were observed. At the beginning of the vocalization activity (Fig. $3-\mathrm{A}$ and $\mathrm{B}$ ) or when far from the chorus, the males emitted notes averaging $38 \mathrm{~ms}$ in duration, with a slow repetition rate ranging from 0.4 to 2 notes per second. The repetition rate of notes may vary in the same series (490-1700 ms; $703 \pm 295 ; \mathrm{n}=38$ series). Three to 12 notes are emitted per series whose average duration is 7 seconds.

The second type is the typical advertisement call emitted by males in choruses (Fig. $3-\mathrm{C}$ and D), often with a high number of individuals. The notes are emitted in regular intervals with an average repetition rate of 3 notes per second. The number of notes per sequence can be higher, ranging from 3 to 35 . The average duration of the note series is 4.7 seconds.

In chorus activity with the note series repeated at regular intervals, a structural characteristic of $H$. sanborni call was observed which is very similar to the corresponding one in H. nana. In H. sanborni, the first note of the series is often longer (introductory note) than the secondary notes (Fig. $3-\mathrm{C}$ and D). These longer notes with a higher pulse number are generally present in the initial calls.

Comparing the initial call and the chorus call (see Table 1 for acustic parameters), significant statistical differences were found in the number of notes emitted, repetition rate of notes, and sequence duration (Mann-Whitney rank sum test $\mathrm{p}<0.0001$ ). No significant differences between pulse duration and between rates of pulse repetition were found (Mann-Whitney rank sum test $\mathrm{p}<0.0001$ ). 


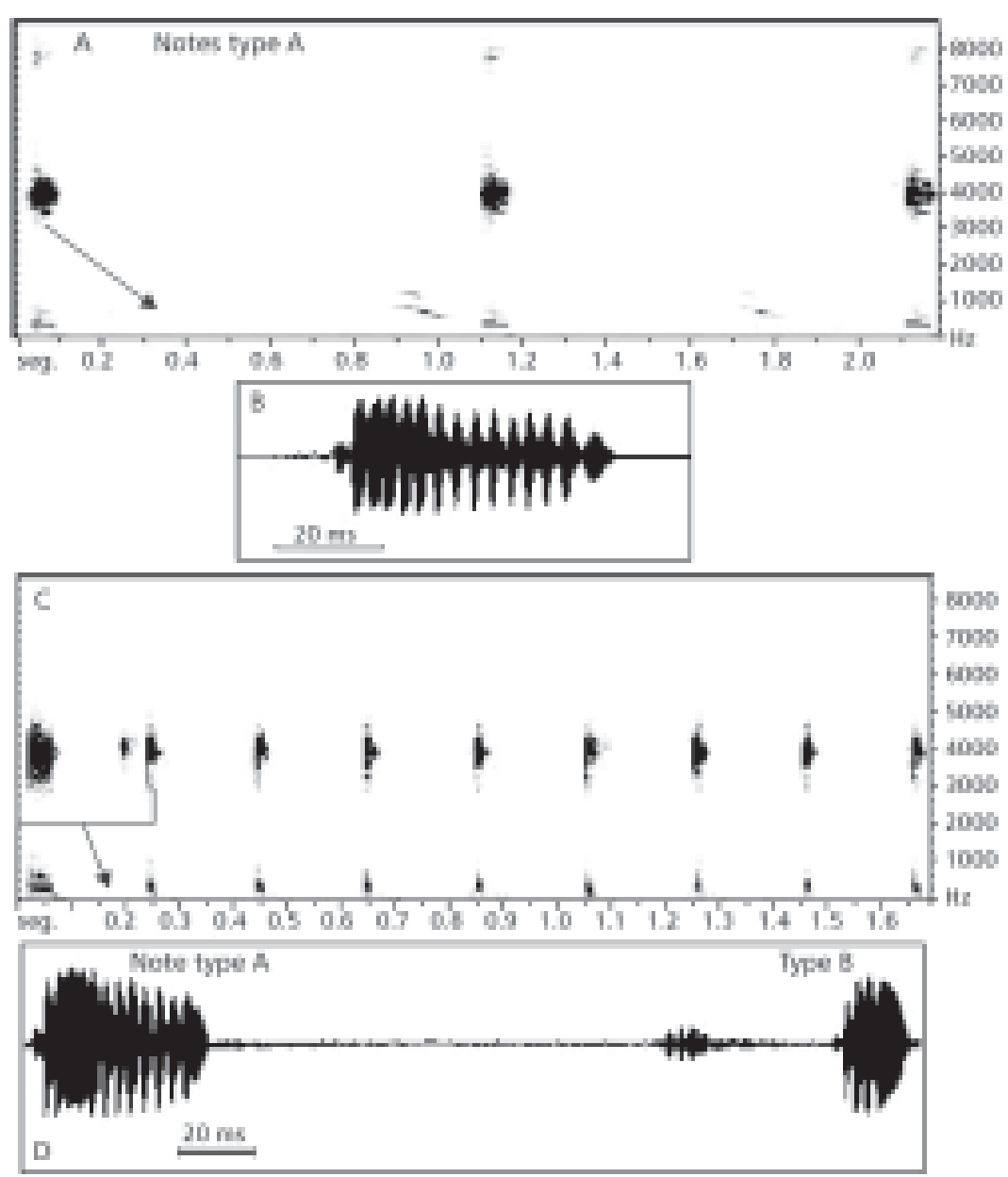

Fig. 1 - Advertisement call of Hyla nana. Sonogram (A) oscillogram (B) of the first note in beginning vocalization (18:35 h), with type A notes only. Air temperature $20^{\circ} \mathrm{C}$, water temperature $23^{\circ} \mathrm{C}$; September 19,1997 . Sonogram (C) and oscillogram (D) of type A (first) and B notes during chorus activity $\left(21: 10 \mathrm{~h}\right.$ ). Air temperature $21^{\circ} \mathrm{C}$, water temperature $22^{\circ} \mathrm{C}$.
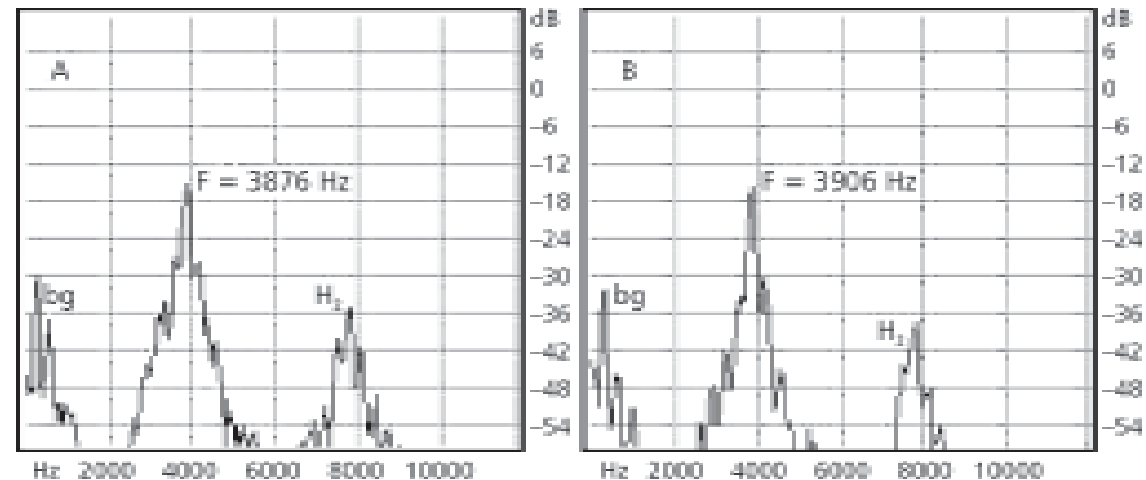

Fig. 2 - Advertisement call of Hyla nana: power spectrum of type A - introductory (A), and type B - secondary notes (B), showing frequency bands and note intensity. Energy concentration around $3900 \mathrm{~Hz}$, and $\mathrm{H}_{2}$ around $7850 \mathrm{~Hz}$ (bg = backgound; $\mathrm{F}$ = fundamental frequency; $\mathrm{H}_{2}=$ second harmonic). 

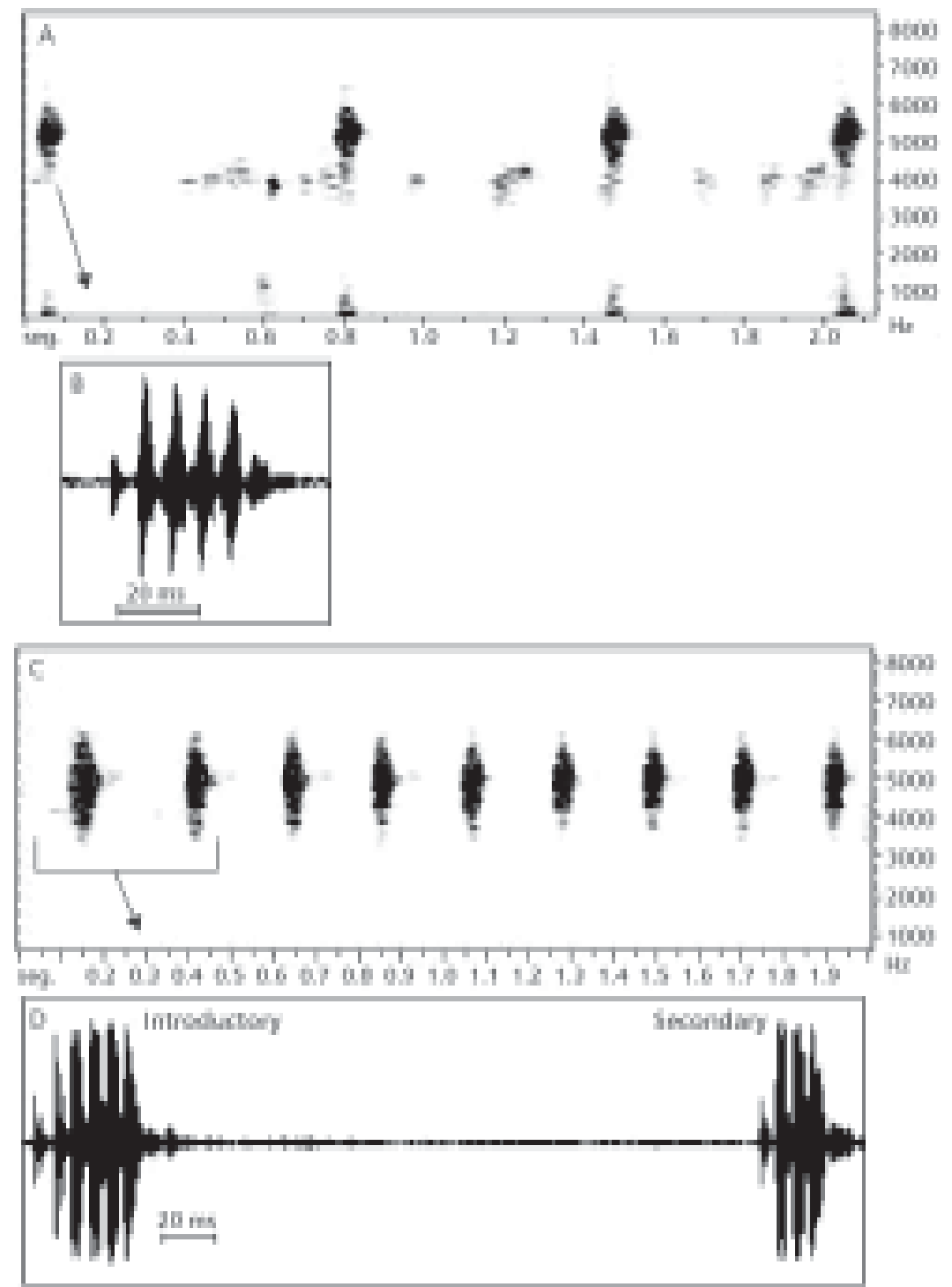

Fig. 3 - Advertisement call of Hyla sanborni. Sonogram (A) and oscillogram (B) of call segment at the beginning of vocalization $(18: 40 \mathrm{~h})$. Air temperature $20^{\circ} \mathrm{C}$, water temperature $21^{\circ} \mathrm{C}$; August 21, 1998. Sonogram (C) and oscillogram (D) during chorus activity (first note - introductory). Air temperature $20^{\circ} \mathrm{C}$, water temperature $21^{\circ} \mathrm{C}$; August $21,1998$.

\section{DISCUSSION}

Anuran calls, especially the advertisement calls (sensu Wells, 1977) emitted by males during the reproductive period, are very important in systematics. The study of vocalization may be of importance in species identification and in phylogenetic analysis of related species (De La Riva et al., 1995).

The advertisement call of frog species may be either a single note or a series of identical no- tes or a complex combination of one or more notes or note groups with different acoustic properties. These call types are common in most hylids (Duellman, 1970).

The advertisement call of the species studied in the present paper consists in the emission of a consecutive series of simple notes with relatively fast repetition rates. The vocalization behavior of both species is associated with different moments in the social organization. 


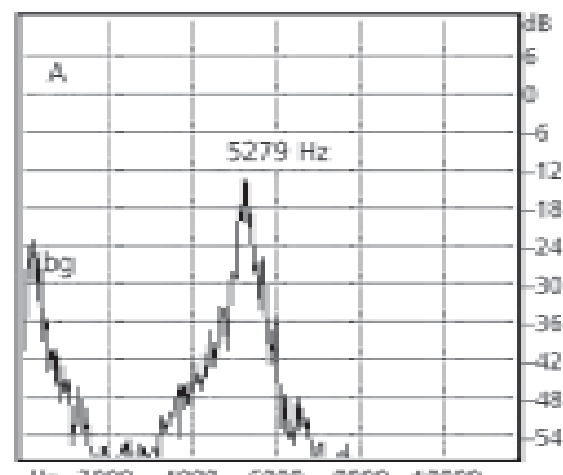

He 2000 4000 6000 aco0 tosot

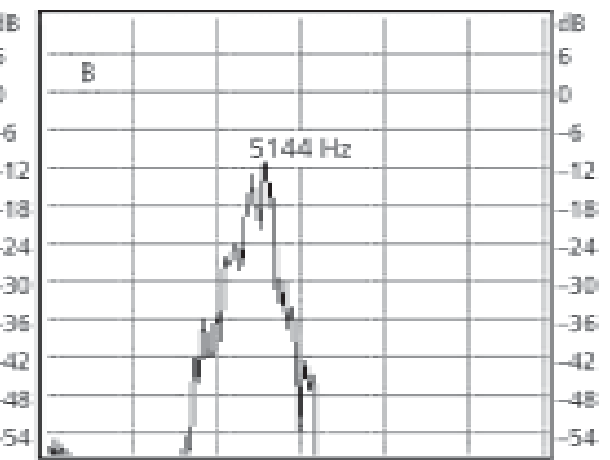

He 2000 4000 6000 3000 10000

Fig. 4 - Advertisement call of Hyla sanborni: power spectrum of (A) first note (type A - Introductory), note intensity and energy concentration at around $5200 \mathrm{~Hz}$. (B) Secondary note (type B), frequency band and highest intensity during chorus at around $5100 \mathrm{~Hz}$ (bg = background; $\mathrm{F}=$ fundamental frequency).

At the beginning of the vocalization activity or in isolated individuals, emission rate is lower. During chorus activity, on the other hand, both rates and note number per series are higher. This variation in vocalization behavior is related to the presence of other vocalizing males in the vicinity. The same patterns have been observed in Hyla ebrecata, $H$. phlebodes, and H. microcephala by Schwartz \& Wells (1984b, 1985), Wells \& Schwartz (1984), and Wells (1988).

Wells \& Taigen (1986) observed $H$. versicolor males alter their call behavior in response to changes in the social organization of the group. According to these authors, the males spend little energy in vocalization when few of them are present, but increase vocalization efforts when competition among males is intense. In the species under discussion, this change was marked by increased rates during chorus singing. The difference in rhythm before and during chorus activity demonstrates that these behavioral differences are important in social organization and that this fact must therefore be considered in bioacoustic analysis.

We found that in $H$. nana and $H$. sanborni the introductory notes differ in temporal structure from the secondary notes. The introductory notes were constant during chorus calling. Several anuran species are known to have advertisement calls with two or more note types: one introductory long note is followed by shorter secondary notes (Fouquette Jr., 1960; Allen, 1973; Wells, 1988; De La Riva et al., 1995; Matsui, 1996; Bosch et al., 2000; Grafe et al., 2000). The introductory notes of the advertisement call have been associated with social behavior in the organization of the chorus (Schwartz, 2001). According to Allen (1973), advertisement calls have different note types, namely introductory and secondary, but with equal spectral structure, functioning in both sexual attraction and spacing retention among choir neighbors.

Chorus vocalizations with introductory and secondary notes differing in temporal structure have been associated with chorus territorialization, enhancing call site occupation and spacing among males. Duellman \& Fouquette (1968) report that the basic call pattern of the Hyla microcephala species group is formed by one introductory note followed by different secondary series with different patterns of temporal duration. We found this pattern in H. nana, a species once included in the microcephala group by Duellman (1970). This call pattern may represent a phylogenetic trait of these species.

The advertisement call of $H$. nana in Botucatu presents acoustic charateristics similar to those recorded in other localities (Basso et al., 1985; Cei, 1987; Marquez et al., 1993; Del Grande, 1995; Rossa-Feres \& Jim, 2001).

In Argentina, the advertisement call of $H$. nana was reported by Basso et al. (1985) to fall in the frequency range between 2750 and $5200 \mathrm{~Hz}$, with the highest intensity between 3500 and $4400 \mathrm{~Hz}$, and energy peak in $3800 \mathrm{~Hz}$, while Cei (1987) reports a fundamental frequency of around $4000 \mathrm{~Hz}$. In Bolivia, on the other hand, Marquez et al. (1993) 
reported for the same species a frequency range from 2649 to $4854 \mathrm{~Hz}$, with strong energy concentration between 3500 and $4500 \mathrm{~Hz}$, and dominant frequency at $4526 \mathrm{~Hz}$. In the present study, the energy peak or the area of concentration occur at around 3900 $\mathrm{Hz}$, in agreement with the data presented by the above-mentioned authors.

The data of Marquez et al. (1993) indicate that the different call notes (here named types $\mathbf{A}$ and $\mathbf{B}$ ) and the different behavioral moments (beginning of vocalization and chorus) were analysed together. Hence, they reported note duration from 28 to 55 $\mathrm{ms}$, with 5 to 14 pulses, and variation in repetition rate ranging from 29 to 193 notes per minute. If the same procedure had been adopted here, the results would be rather similar.

In Botucatu, the advertisement call of $H$. sanborni has an average frequency range of between 3860 and $5950 \mathrm{~Hz}$, dominant frequency between 4000 and $5500 \mathrm{~Hz}$, and the highest energy concentration at around $5100 \mathrm{~Hz}$ (= fundamental).

Describing a central Amazonian species of the nana group ("H. cf. nana"), Hödl (1977) reported a frequency band between 4500 and $5600 \mathrm{~Hz}$ and a dominant frequency of $4835 \mathrm{~Hz}$. These data are very similar to those obtained in the present study for H. sanborni.

Studying the advertisement call of $H$. sanborni in Campinas (São Paulo), Cardoso (1981) reported a frequency range between 3.2 and $6.5 \mathrm{kHz}$, with dominant frequency between 4.6 and $5.8 \mathrm{kHz}$ and notes presenting eight pulses an average with duration of 60 ms. In Corumbataí (São Paulo), Del Grande (1995) reported a frequency band of 3.8 and $6.0 \mathrm{kHz}$ and notes with from 4 to 6 pulses of 20 to $50 \mathrm{~ms}$ in duration. Our data from Botucatu are similar to those above. The differences may be related to differences in the equipment utilized in call analysis and to separation of the analyses according to behavioral moments.

Basso et al. (1985) describe the high frequency band of $H$. sanborni in Argentina as ranging from 4000 to $5800 \mathrm{~Hz}$, with an energy peak at around $4900 \mathrm{~Hz}$, in agreement with the data from Botucatu.

$H$. nana and $H$. sanborni present more complex calls than are mentioned until now in the literature. The vocalizations made up of introductory and secondary notes are associated with social organization in chorus, and are a function of sexual attraction and territorial conditions, and serve to reinforce occupation of the call site.
The existence of synchronotopic, closely related populations in Botucatu is favored by interactive behavior, population fluctuations, and differences in the spectral and temporary structures of the advertisement calls which are strong mechanisms in effective of acoustic partitioning, mainly during chorus activities when the competition for acoustic space is greater among the individuals in the group.

Acknowledgments - We thank Dr. Jacques M. E. Vielliard for his valuable suggestions and advice. We are grateful to Dr. Elieth F. Spirandeli Cruz, Rosangela A. Marques, Silvio C. Almeida, and Benedito R. Cardana for their valuable comments and help in field work. Dr. Nelson Bernardi helped with the English version. Dr. Maria Helena de A. Leme provided statistical support. The first author is grateful to the Universidade de Taubaté (UNITAU) for financial support (process n. BIO - 159/97 - PRPPG).

\section{REFERENCES}

ALLEN, D. M., 1973, Some relationship of vocalization to behavior in the Pacific treefrog, Hyla regilla. Herpetologica, 29: $366-371$

AYRES, M., AYRES, Jr. M., AYRES, D. L. \& SANTOS, A. S., 2000, BioEstat 2.0: aplicações estatísticas nas áreas das ciências biológicas e médicas. Sociedade Civil Mamirauá, CNPq, Brasília, 259p.

BASSO, G. N., PERI, S. I. \& DI TADA, I. E., 1985, Revalidación de Hyla sanborni, Schmidt, 1944 (Anura, Hylidae). Cuad. Herp., 1(3): 1-11.

BASTOS, R. F. \& HADDAD, C. F. B., 1995, Vocalizações e interações acústicas em H. elegans (Anura, Hylidae) durante a atividade reprodutiva. Naturalia, 20: 165-176.

BOSCH, J., DE LA RIVA, I. \& MÁRQUEZ, R., 2000, Advertisement calls of seven species of hiperoliid frogs, from Equatorial Guinea. Amphibia-Reptilia, 21: 246-255.

CARDOSO, A. J., 1981, Organização espacial e temporal na reprodução e vida larvária em uma comunidade de hilídeos no Sudeste do Brasil (Amphibia, Anura). Dissertação de Mestrado, IB, Universidade Estadual de Campinas, UNICAMP, 106p.

CARDOSO, A. J., 1986, Utilização de recursos para reprodução em comunidade de anuros no Sudeste do Brasil. Tese de Doutorado, IB, Universidade Estadual de Campinas, UNICAMP, 216p.

CARDOSO, A. J. \& VIELLIARD, J., 1990, Vocalização de anfíbios anuros de um ambiente aberto, em Cruzeiro do Sul, Estado do Acre. Rev. Bras. Biol., 50(1): 229-242.

CEI, J. M., 1987, Additional notes to "Amphibians of Argentina": an update, 1980-1986. Monitore Zool. Ital. (N.S.), 21: 209272.

COCROFT, R. B. \& RYAN, M. J., 1995, Patterns of advertisement call evolution in toads and chorus frogs. Anim. Behav., 49: 283-303.

DE LA RIVA, I., MÁRQUEZ, R. \& BOSCH, J., 1995, Advertisement calls of eight Bolivian hylids (Amphibia, Anura). J. Herpetol., 29(1): 113-118. 
DE LA RIVA, I., MÁRQUEZ, R. \& BOSCH, J., 1996a, The advertisement calls of three South American poison frogs (Amphibia: Anura: Dendrobatidae), with comments on their taxonomy and distribution. Journal of Natural History, 30 : 1413-1420.

DE LA RIVA, I., MÁRQUEZ, R. \& BOSCH, J., 1996b, Advertisement calls of microhylid frogs from Bolívia (amphibia, Anura). Am. Midl. Nat., 136: 418-422.

DEL GRANDE, M. L., 1995, Estudo comparado da biologia de Hyla nana e de Hyla sanborni (Amphibia, Anura, Hylidae) em Corumbataí, Estado de São Paulo. Dissertação de Mestrado, Universidade Estadual Paulista, UNESP, 70p.

DUELLMANN, W. E., 1970, The hylidae frogs of Middle America. Monogr. Mus. Nat. Hist. Univ. Kansas, (1): 1-753.

DUELLMAN, W. E. \& FOUQUETTE, Jr. M. J., 1968, Middle American frogs of the Hyla microcephala group. Univ. Kansas Publ. Mus. Nat. Hist., 17(12): 517-557.

DUELLMAN, W. E. \& PYLES, R. A., 1983, Acoustic resource partitioning in anuran communities. Copeia, (3): 639-649.

DUELLMAN, W. E. \& TRUEB, L., 1986, Biology of Amphibians. McGraw-Hill, New York, 670p.

FOUQUETTE Jr., M. J., 1960, Isolating mechanisms in three sympatric treefrogs in the Canal Zone. Evolution, 14(4): 484-497.

FROST, D. R., 1985, Amphibians species of the world. Allen Press, Inc. and the Association of Systematic Collections, Lawrence, vi $+722 p$.

GERHARDT, H. C., 1994, The evolution of vocalization in frogs and toads. Ann. Rev. Syst., 25: 293-324.

GIVEN, M. F., 1999, Frequency alteration of the advertisement calls in the carpenter frog, Rana virgatipes. Herpetologica, 55(3): 304-317.

GRAFE, T. U., 1996, The function of call alternation in the African reed frog (Hyperolius marmoratus): precise call timing prevents auditory masking. Behav. Ecol. Sociobiol., 38: $149-158$

GRAFE, T. U., STEFEN, J. O. \& STOLL, C., 2000, Vocal repertoire and effect of advertisement call intensity on calling behaviour in the West African tree frog, Leptopelis viridis. Amphibia-Reptilia, 21: 13-23.

HÖDL, W., 1977, Call differences and calling site segregation in anuran species from central Amazonian floating meadows. Oecologia (Berl.), 28: 351-363.

JIM, J., 1980, Aspectos ecológicos dos anfíbios registrados na região de Botucatu, São Paulo (Amphibia, Anura). Tese de Doutorado, IB-USP, Universidade de São Paulo, 332p.

MÁRQUEZ, R., DE LA RIVA, I. \& BOSCH, J., 1993, Advertisement call of Bolivian species of Hyla (Amphibia, Anura, Hylidae). Biotropica, 25(4): 426-443.

MARTIN, P. \& BATESON, P., 1986, Measuring behaviour an introductory guide. Univ. Press., Cambridge, pp. 1-199.

MATSUI, M., 1996, Call characteristics and systematic relationships of a Malayan treefrog Nyctixalus pictus (Anura, Rhacophoridae). Herpetological Journal, 6: 62-64.
PASSMORE, N. I., 1981, The relevance of the specific mate recognition concept to anuran reprodutive biology. Monitore Zool. Ital., 6: 93-108.

ROSSA-FERES, D. C. \& JIM, J., 2001, Similaridade do sítio de vocalização em uma comunidade de anfíbios anuros da região Noroeste do Estado de São Paulo, Brasil. Revta. Bras. Zool., 18(2): 439-454

RYAN, M. J., 1985, The túngara frog: a study in sexual selection and communication. University of Chicago Press, Chicago, 230p.

RYAN, M. J., 2001, Anuran communication. Smithsonian Institution Press, Washington, London, 252p.

SALTHE, S. N. \& MECHAM, J. S., 1974, Reproductive and courtship patterns. In: B. Lofts (ed.), Physiology of the Amphibia. Academic Press, New York, vol. II, pp. 309-521.

SCHWARTZ, J. J., 2001, Call monitoring and interactive playback systems in the study of acoustic interactions among male anurans. In: M. J. Ryan (ed.), Anuran Communication. Smithsonian Institution Press, Washington, London, pp. 183204.

SCHWARTZ, J. J. \& WELLS, K. D., 1983, An experimental study of acoustic interference between two species of neotropical treefrogs. Anim. Behav., 31: 181-190.

SCHWARTZ, J. J. \& WELLS, K. D., 1984a, Interspecific acoustic interactions of the neotropical treefrog Hyla ebraccata. Behav. Ecol. Sociobiol., 14: 211-224.

SCHWARTZ, J. J. \& WELLS, K. D., 1984b, Vocal behavior of the neotropical treefrog Hyla phlebodes. Herpetologica, 40: $452-463$.

SCHWARTZ, J. J. \& WELLS, K. D., 1985, Intra and interspecific vocal behavior of the neotropical treefrog Hyla microcephala. Copeia, pp. 27-38.

VIELLIARD, J. M. E. \& CARDOSO, A. J., 1996, Adaptação de sinais sonoros de anfíbios e aves a ambientes de riachos com corredeiras. In: J. E. Pefaur (ed.), Herpetologia neotropical. Acta Del II Congresso Latino Americano de Herpetologia, Universidad de Los Andes. Consejo de Desarrolo, Humanistico y Tecnológico, Merida, Venezuela, vol. 2, pp. 97-119.

WELLS, K. D., 1977, The social behaviour of anuran amphibians. Anim. Behav., 25: 666-693.

WELLS, K. D., 1980, Intra and interspecific comunication in the neotropical frog Hyla ebraccata. Amer. Zool., 20(4): 724.

WELLS, K. D., 1988, The effect of social interations on anuran vocal behavior. In: B. Fritzsch, M. J. Ryan, W. Wilczynski, T. E. Hetherington \& W. Walkowiak (eds.), The evolution of amphibian auditory systems. John Wiley and Sons, New York, pp. 433-454.

WELLS, K. D. \& SCHWARTZ, J. J., 1984, Vocal communication in a neotropical treefrog, Hyla ebraccata: aggressive calls. Behaviour, 91: 128-145.

WELLS, K. D. \& TAIGEN, T. L., 1986, The effect of social interactions on calling energetics in the gray treefrog ( Hyla versicolor). Behav. Ecol. Sociobiol., 19: 9-18. 